\title{
Valtakunnansuunnittelun nykyinen vaihe Suomessa
}

\author{
Kirjoittanut Johannes Virolainen. \\ Valtakunnansuunnittelun tarpeellisuus.
}

Lokakuun 19 päivänä 1951 tekemällään päätöksellä valtioneuvosto asetti valtakunnansuunnittelukomitean, jonka saamansa tehtävän mukaisesti oli:

1) laadittava selvitys siitä, mitä valtakunnansuunnitteluun liittyviä tehtäviä meillä eri viranomaisten ja järjestöjen toimesta jo on suoritettu ja parhaillaan suoritetaan sekä miten laaditut selvitykset ja tehdyt suunnitelmat olisi sovitettava yhteen ottamalla huomioon koko kansantalouden vaatimukset;

2) selvitettävä, mitkä valtakunnansuunnittelun kannalta tärkeät tehtävät vaativat kiireellistä ratkaisua, ja tehtävä ehdotus tässä tarvittavista toimenpiteistä; sekä

3) tehtävä ehdotus valtakunnansuunnittelun organisaatiosta.

Voidaan sanoa, että meillä on nyt ensimmäisen kerran valtiovallan taholta ryhdytty toimenpiteisiin koko valtakuntaa koskevan, tieteelliseen tutkimustyöhön ja tilastollisiin selvityksiin perustuvan yleissuunnittelun aikaansaamiseksi. Toimenpide on seurauksena yleisestä vakaumuksesta, että yhteiskuntajärjestyksen perusteista riippumatta tarvitaan suuria ongelmia ratkaistaessa edeltä päin tapahtuvaa suunnittelutoimintaa. Koko valtakuntaa koskevia ratkaisuja tehtäessä on varmasti hyödyksi, jos ratkaisun suorittajilla, eduskunnalla ja hallituksella, on käytettävissään tosiasioihin perustuvia tietoja erilaisista ratkaisumahdollisuuksista. 
Edellä tarkoitettuja suuria ongelmia ovat $\mathrm{mm}$. voimalaitosten rakentaminen, laajasuuntaiset kuivatustyöt, uuden pellon raivaaminen, asuntojen rakentaminen, teollisuuden sijoitus valtakunnan eri osiin, verotuspolitiikka ja hallinnon kehittäminen. Yleensä joudutaan tällaisia ratkaisuja tehtäessä asettamaan kysymys, miten saavutetaan kokonaisuuden kannalta tehokkain taloudellinen tulos. Ratkaisun suorittaminen jää joka tapauksessa valtakunnan poliittisen johdon vastuulle. Mutta jos sillä ei ole käytettävissään faktoja, päätökset joudutaan tekemään sattumanvaraisesti, paikallisten, puolue- jopa henkilökohtaisten näkökohtien nojalla. Jotta suuret ongelmat kyettäisiin näkemään valtakunnallisessa perspektiivissä, täytyisi kukin yksityiskohta asettaa oikeaan suhteeseen valtakunnalliseen kokonaisuuteen nähden.

\section{Mitä valtakunnansuunnittelu on?}

Käsite valtakunnansuunnittelu (riksplanering, Landesplanung, national planning, general planning, town and country planning) on meillä verraten uusi. Vasta toisen maailmansodan jälkeen on siitä yleisemmin puhuttu ja kirjoitettu. Mutta suunnittelu sinänsä ei meilläkään ole uutta. Eri yhteyksissä on laadittu mitä erilaisimpia ohjelmia. Vika on vain ollut siinä, että suunnittelut ovat olleet liiaksi erillisiä, ne ovat olleet irrallisia ja toisiinsa sopeutumattomia. Sopusointuisuuden, pharmonisuuden asemesta on erillisratkaisujen seurauksena syntynyt kasaantumista ja jännitystä.

Epäkohdat ja puutteet on yritettävä korjata yleissuunnittelulla, joka saattaa erillissuunnitelmat sopusointuun keskenään ja valtakunnan etujen kanssa. Tällainen suunnittelu kuuluu valtakunnঞlliselle elimelle, jonka pätevyydestä ja puolueettomuudesta on saatava takeet. Kauastähtäävät suunnittelut kuuluvat siten yhteiskunnalle, joka niiden avulla huolehtii tulevienkin sukupolvien toimeentulosta ja tämän tekemisestä nykyistä helpommaksi.

Jos nyt kysytään, onko valtakunnansuunnittelu sitten maankäytön, asutuksen, teollisuuden tai muun sellaisen suunnittelua, 
on sanottava, ettei mikään näistä vielä sellaisenaan ole valtakunnansuunnittelua. Viimeksi mainittu ei ole erillistä suunnittelua, vaan se antaa erillisille suunnitelmille valtakunnallista sisältöä ja kokonaisuuteen sopivan tarkoituksen. Voitaisiin sanoa, että valtakunnansuunnittelu on yhteiskunnan pitkällä tähtäimellä suorittamaa olojen järjestely- ja ohjaustoimintaa. Sen tarkoituksena on luoda edellytykset jonkin maan tuotantovoimien hyväksikäytölle kansakunnan hyvinvointia ja onnellisuutta parhaiten edistävällä tavalla. Tuotantovoimiin luetaan tällöin kaikki sanottua tarkoitusta edistävät aineelliset ja henkiset varat.

\section{Väestöolot.}

Lähdettäessä tarkastelemaan valtakunnansuunnitteluun liittyviä moninaisia ongelmaryhmiä joudutaan ensin inventoimaan, luetteloimaan ja kartoittamaan valtakunnan tärkeimmät voimavarat. Kun puhutaan voimavarojen kartoittamisesta, niin tarkoitetaan niiden alueellisen sijainnin selvittämistä. Valtakunnansuunnittelukomitea on tässä voimavarojen luetteloimistyössä lähtenyt Suomen väestösuhteitten yksityiskohtaisesta selvittelystä. Tarkoituksena on saada kuva väestöolojemme kehityksestä viime kolmenkymmenen vuoden aikana. Tällöin kiinnitetään erityistä huomiota tapahtuneisiin sisäisiin eli maan eri osien välisiin väestönmuuttoihin ja toisaalta maastamuuttoon eli siirtolaisuuteen. Edelleen selvitetään väestön elinkeinoryhmityksen, ikärakenteen ja sukupuoliryhmityksen muutokset sekä laaditaan ennusteita, prognooseja, odotettavissa olevasta väestönkehityksestä. Kaikkia edellä mainittuja muutoksia tarkastellaan alueellisesti. Sen vuoksi laaditaan pääosa mainituista selvityksistä kunnittain. Kun väestösuhteitten selvitys, jonka tiedot saadaan väestötilastoista ja merkitään kunnittain laadittavaan väestökortistoon, on valmistunut, on saatu yksi tärkeä peruste valtakunnan ja sen eri osien tulevan kehityksen suunnittelutyölle. Jo tähän mennessä suoritettujen yleisluontoisten selvitysten perusteella voidaan mm. todeta, että se sisäinen muuttoliike, jonka suunta on vuosisatoja kulkenut etelä- ja lounais-Suomesta pohjoista ja koillista kohden, 
rintamailta harvaan asutuille seuduille, on viime kolmenkymmenen vuoden aikana jotenkin kokonaan pysähtynyt. Sen sijaan on alkanut uusi muuttoliike, jonka suunta on päinvastainen edellä mainitun suunnan kanssa eli pohjoisesta etelään ja koillisesta lounaaseen. Lähtemättä tätä kysymystä yksityiskohtaisesti selvittämään on syytä todeta, että maan eri osien välinen väestönvirta, joka vielä viime vuosisadan lopussa ja tämän vuosisadan alussa johti väestöntiheyden tasoittumiseen valtakunnan eri osien kesken, on käytännöllisesti katsoen pysähtynyt, ja on alkanut uusi virtaus, joka johtaa jatkuvasti kasvaviin maan eri osien väestöntiheyden eroihin.

Juuri väestön alueellinen jakautuminen valtakunnan eri osien kesken on tärkeätä tietää, kun suunnitellaan esim. toimenpiteitä työvoiman mahdollisimman tehokkaan käytön aikaansaamiseksi. Eräillä alueilla saattaa nykyään olla jatkuvaa puutetta työvoimasta, mutta toisaalta on alueita, joilla työvoimaa on liian paljon. Valtakunnan talouselämän häiriintymätön kulku edellyttää tuotannon sijoittumista siten, että työvoima tulee tehokkaasti käytetyksi, jotta saavutetaan mahdollisimman korkea täystyöllisyyden aste. - Väestön ikä- ja sukupuolirakentteessa, jolla on huomattava merkitys työllisyyden kannalta, saattaa myös olla alueellisesti varsin suuria eroavuuksia.

Väestöntiheyden liiallisten eroavuuksien tasoittaminen ja pyrkimys päästä kokonaisuuden kannalta mahdollisimman edulliseen väestön- ja asumistiheyteen on keskeisiä pyrkimyksiä valtakunnallisessa suunnittelutyössä. Niinpä esim. Englannissa valtakunnansuunnittelua tarvitaan ennen muuta sen vuoksi, että väestön- ja asumistiheys eräissä keskuksissa on liian suuri. Liiallisesta kasaantumisesta aiheutuu paitsi sosiaalisia myös taloudellisia epäkohtia. Valtakunnallinen suunnittelutyö Englannissa lähtee näin ollen pääasiassa keskuksista käsin, joista suurimpia, ennen muuta Lontoota, pyritään pienentämään ja hajoittamaan väestö nykyistä tasaisemmin maan eri osiin. Meillä - samoin kuin Ruotsissa ja Norjassa - lähtökohta on kokonaan toinen. Meillä on pintaalaltaan laaja maa ja vähäinen asukasmäärä. Meillä valtakunnan- 
suunnittelussa joudutaan kiinnittämään huomiota ensi sijassa niihin ongelmiin, jotka johtuvat liian harvasta asutuksesta. Ohjausja järjestelytoimenpiteillä on edistettävä väestön tasaista jakautumista valtakunnan eri osiin. Näin joudutaan harkitsemaan keinoja, joilla voitaisiin estää liian suuri väestön keskittyminen ja toisaalta väestöntiheyden painuminen liian alhaiseksi.

\section{Tuotannon alueelliset edellytykset.}

Yleissuunnittelulle muodostaa väestösuhteitten selvittelyn ohella toisen keskeisen lähtökohdan talouselämän nykyisen tilan ja kehitysmahdollisuuksien tarkastelu. Tällöin kiinnitetään päähuomio ns. primääri- eli alkutuotannon alueellisiin edellytyksiin. Valtakunnansuunnittelukomitea on tässä selvittelytyössä tutustunut niihin suunnitelmiin, joita on laadittu talouselämän kehittämismahdollisuuksista valtakunnan eri osissa ja erityisesti ns. jäljelle jääneillä alueilla. Viimeksimainituilla tarkoitetaan sellaisia osia valtakunnastamme, joiden talouselämä ei kykene tarjoamaan riittävää toimeentuloa siellä nyt asuvalle väestölle. Tätä kysymystä tarkastellessaan komitea on lähtenyt, voisi sanoa, alhaalta ylös päin eli po. alueiden kunnista ja niiden olosuhteista. On yksityiskohtaisesti tutkittava, mitä mahdollisuuksia kussakin tapauksessa on tehostaa sellaisten luonnonvarojen hyväksi käyttämistä, jotka vielä nyt ovat joko kokonaan hyötyä tuottamatta taikka joita käytetään epätäydellisesti. Toisaalta on selvitettävä, mitkä epäkohdat estävät ja vaikeuttavat alueen talouselämän kehitystä. Tällaisten yksityiskohtaisten tutkimusten perusteella voidaan päätellä, onko po. alueilla yleensä mahdollisuuksia tarjota työtilaisuuksia siellä asuvalle väestölle vai ei.

Ma a- ja metsätalous. Mitä tällöin erityisesti maa- ja metsätalouden kehittämiseen tulee, on tärkeätä laatia yksityiskohtainen selvitys maatalouden erilaisista edellytyksistä valtakunnan eri osissa. On selvää, että pohjois- ja koillis-Suomessa ei voida harjoittaa maataloutta samalla tavalla kuin maan eteläja länsiosissa. Meidän maataloustuotantomme on tällä hetkellä 
liian yksipuolisesti kehittynyt. Kaikkialla valtakunnassa yritetään seurata suurin piirtein samanlaista tuotantosuuntaa. Ei ole riittävässä määrin selvitetty maataloutemme erilaisia alueellisia edellytyksiä eikä ole pyritty tietoisesti sovelluttamaan tuotantoa vaihtelevien edellytysten mukaisesti. Tässä kohden valtakunnallisella suunnittelu- ja tutkimustyöllä on tärkeä tehtävä suoritettavanaan.

Ma a talouskelpoiset alue et. Maatalouden tulevaisuutta suunniteltaessa on tarkoin selvitettävä, kuinka paljon meillä vielä on käytettävissä maatalouskelpoista maata, ts. sellaista maata, joka voitaisiin kannattavasti raivata pelloksi, niityksi tai laitumeksi. Vaikka esim. asutustoiminnan ja valtakunnan metsävarojen linja-arvioinnin yhteydessä onkin suoritettu viljelyskelpoisuustutkimuksia, meillä ei valitettavasti ole täydellistä maatalouskelpoisten alueiden inventaariota. Emme ole selvillä siitä, kuinka paljon maatalouskelpoista maata maassamme on kaikkiaan ja miten tämä on alueellisesti jakautunut. Olisi tärkeätä tietää suorastaan kunnittain, paljonko tällaisia alueita on vielä olemassa. Tässä kohden on suoritettavanamme suuri inventoimistyö, jolla on tärkeä merkitys koko kansantalcutemme tulevaisuutta ajatellen.

$M a$ a näytön su unnittelu. Itse maankäytön suunnittelu on eräs osa valtakunnansuunnittelusta: Meidän olojamme ajatellen on tärkeätä selvittää, mikä maankäyttömuoto kullakin paikkakunnalla ja kussakin tapauksessa on kokonaisuuden kannalta edullisin. On esimerkiksi selvää, että läheskään kaikkia pohjois- ja itä-Suomen viljelyskelpoisia soita ei voida raivata pelloksi. Huomattava osa niistä tulee vastaisuudessakin jäämään metsän kasvuun. Mutta laajasuuntaisia kuivatustöitä suorittamalla on mahdollista parantaa metsätalouden harjoittamisen edellytyksiä laajoilla suoalueilla. Valtakunnansuunnittelukomitea on todennut $\mathrm{mm}$., että meillä ei ole suoritettu selvityksiä siitä, miten puuttomat suoalueet kuivatuksen jälkeen nopeimmin ja taloudellisimmin voidaan saattaa metsää kasvamaan. Tässä tarvitaan yksityiskohtaista tutkimustyötä, jotta voidaan kehittää kussakin tapauksessa parhaiten sopivat taloudelliset menetelmät. 
Maankäyttörajoitukset. Mutta muissakin suhteissa on tärkeätä, että maankäyttömuoto tulee oikein määrätyksi ja että maankäytöstä keskenään kilpailevat vaatimukset tulevat oikealla tavalla punnituiksi. Komitea on kiinnittänyt huomiota mm. siihen seikkaan, että samanaikaisesti kuin meillä raivataan valtion maksamien uudisraivauspalkkioiden turvin uutta peltoa itäja pohjois-Suomeen, monessa tapauksessa varsin karuille ja hallanaroille alueille, tuhlataan ja pirstotaan maata etelä-Suomen parhailla viljelysalueilla. Meillä ei ole minkäänlaisia säännöksiä siitä, ettei esim. I luokan peltomaata saisi käyttää tonttialueiksi, varastoalueiksi ja teollisuus- yms. tarkoituksiin. Kun tällaisia määräyksiä ei ole, parasta peltomaata hävitetään varsinkin eteläSuomen suurten väestökeskusten ympärillä. Vaikka meillä onkin maata suhteellisesti enemmän kuin esim. Englannissa, niin hyvää peltoa on vielä liian vähän. Ennen kaikkea on näin laita maan etelä- ja lounaisosissa. Sen vuoksi olisi annettava maan käyttöä koskevia määräyksiä, esim. sensuuntaisia, ettei parasta peltoa saa käyttää muihin kuin maataloustarkoituksiin, ellei maankäyttömuodon muutos tuota valtakunnalle ilmeisesti suurempaa hyötyä kuin sen käyttö maatalousmaana.

Muutkin maankäyttökysymykset kuuluvat valtakunnansuunnittelun piiriin. Väestökeskuksia rakennettaessa esimerkiksi on harkittava, olisiko niissäkin jätettävä eräitä maa-alueita käytettäväksi jatkuvasti maa- ja metsätaloudellisiin tarkoituksiin. Toisaalta väestökeskusten olojen tarkoituksenmukainen kehittäminen edellyttää, etiä niisıä on riittävästi väljyyttä. Niiden väestö tarvitsee esim. virkistys- ja ulkoilualueita, joita monissa niistä kuitenkin on aivan liian vähän.

Edellä esitetyt viittaukset osoittavat, että maa- ja metsätalouden kohdalla valtakunnansuunnittelun yhteydessä joudutaan ratkaisemaan varsin monipuolisia ja laajakantoisia maankäyttökysymyksiä. Niiden ratkaiseminen valtakunnallisesti edullisella tavalla edellyttää lainsäädännöllisiä toimenpiteitä. Sen vuoksi olisi saatava aikaan uusi maankäyttölaki, missä määriteltäisiin ne näkökohdat, jotka kulloinkin on otettava huomioon maankäyttöä ratkaistaessa. 
Teollis u u den sijoit us. Maa- ja metsätalouden alueellisesta sijoittumisesta päätettäessä joudutaan lähtemään pääasiassa siitä vaatimuksesta, että tuotanto on sopeutettava kunkin seudun luontaisiin edellytyksiin. Sitä vastoin teollisuuden sijaintikysymyksiä ratkaistaessa on yleensä useampia vaihtoehtoja. Lähtemättä tässä laajalti analysoimaan teollisuuden tuotantopaikan valintaan vaikuttavia tekijöitä on kuitenkin aiheellista tuoda esiin eräitä näkökohtia, joihin valtakunnallisessa suunnittelutyössä on kiinnitettävä huomiota.

Sijaintipaikan valintaan vaikuttavat teki$\mathrm{j}$ ät. Teollisuus on maa- ja metsätalouteen verrattuna vähän tilaa vaativa tuotantomuoto. Sen alueellista sijoittumista tarkasteltaessa voidaan ensin erottaa sellainen teollisuus, joka on kiinteästi paikkaan sidottu. Tällaista teollisuutta on esim. malmin nosto, joka tietysti voi tapahtua vain siellä, missä malmia on. Mutta kun tulee kysymykseen nostetun raaka-aineen jalostaminen, niin sijaintipaikan valinnassa on jo enemmän vaihtoehtoja. Samoin on asianlaita kaikkiin niihin teollisuuksiin nähden, joiden raakaaineita voidaan kuljettaa tai joiden raaka-aineita on saatavissa mistä tahansa. Kaavamaisesti voitaisiin sanoa, että jalostuslaitos voi sijaita raaka-aineen hankintapaikassa tai sen välittömässä läheisyydessä tai valmiiden tuotteiden markkinapaikalla taikka sitten raaka-aineen hankintapaikan ja markkinapaikan välillä. Valintamahdollisuudet riippuvat toisaalta markkinoista, toisaalta ensisijaisesti raaka-aineiden ja valmiiden tuotteiden kuljetuskustannusten välisistä suhteista. Muita sijaintipaikan valintaan vaikuttavia tekijöitä ovat käyttövoiman saanti, työvoiman liikkuvuus ja monet sosiaaliset tekijät, kuten esim. asuntojen saantimahdollisuudet.

Kun tarkastellaan yritysten alueellista sijoittumista meidän maassamme, täytyy todeta, ettei paikan ratkaisua ilmeisestikään aina ole suoritettu taloudellisten tekijöiden perusteella. Yrittäjällä ei ole edes ollut käytettävissään tarpeellisia tietoja, jotta hän olisi voinut vertailla eri alueiden suhteellista edullisuutta. Toisaalta yrittäjien toimintavapautta ovat rajoittaneet monet te- 
kijät. Uusi yrittäjä voi esim. saada luottoa kotiseudultaan paremmin kuin aivan vieraalta paikkakunnalta. Hän perustaa pienen yrityksen, ja kun se menestyy ja kasvaa, yrityksen sijaintipaikkaa on myöhemmin vaikeata muuttaa, vaikka sillä saattaisi jossakin toisessa paikassa olla taloudellisesti paljon paremmat edellytykset. Kun tähän lisäämme vielä sen, että useat kunnat harjoittavat varsin monipuolista subventiopolitiikkaa houkutellakseen alueelleen tuotantolaitoksia, toteamme, että teollisuuden sijoittuminen ei valtakunnallisesti katsoen läheskään aina ole ratkaistu taloudellisten tekijöiden perusteella.

Kuljetuskustannukset. Sijoituspaikan valintamahdollisuudet kasvavat yleensä markkinoiden laajetessa. Samoin ne lisääntyvät, kun raaka-aineiden ja tuotteiden kuljetuskustannukset vähenevät suhteessa painoyksikön arvoon.

Pääasiallisesti edellä mainituista tekijöistä riippuen tuotanto hakeutuu sellaiselle paikalle, missä saavutetaan paras kannattavuus, ts. tarjolla olevista useista sijaintipaikoista valitaan se, mikä tarjoaa parhaat edellytykset yritykselle. Kuljetuskustannusten vaikutus on tällöin hyvin ratkaiseva. Ne muodostuvat toisaalta raaka-aineiden ja muiden tuotannossa tarvittavien tarvikkeiden kuljetuksesta tuotantopaikalle ja toisaalta valmiiden tuotteiden kuljetuskustannuksista. Muista sijaintipaikan valintaan vaikuttavista taloudellisista tekijöistä mainittakoon kustannukset itse tuotantopaikalla. Mutta taloudellisten tekijöiden ohella sijaintipaikan valintaan vaikuttavat myös ns. subjektiiviset tekijät. Yritys sijoitetaan sellaiselle paikalle, mitä pidetään jostain muusta syystä sopivana, missä esim. yrittäjän ja työntekijäin oletetaan viihtyvän hyvin.

R a u t tietariffit. Tarkasteltaessa edellä mainittujen taloudellisten tekijöiden vaikutusta teollisuuden sijaintipaikan määräytymiseen on otettava huomioon, että yksityisen teollisuuslaitoksen kannalta edullisin ratkaisu ei ilmeisesti läheskään aina ole samalla valtakunnallisesti edullisin ratkaisu. Niinpä yritys ottaa kustannuslaskelmissaan huomioon todelliset rautatietariffit, laskee voiman hinnan sen mukaan, mitä siitä kullakin paikka- 
kunnalla laskutetaan, ja samoin selvittää, mitä mahdollisuuksia eri paikkakunnat tarjoavat työntekijöiden asuntokysymyksen ratkaisemiseksi. Kun meillä rautateiden kuljetustariffit perustuvat toisaalta tavaroiden luokitukseen, jossa kuljetusmaksu on sitä alempi, mitä painavammasta tavarasta on kysymys, ja toisaalta ns. etäisyysalennukseen, eivät tariffien perusteella lasketut kuljetuskustannukset osoita erilaisten kuljetusten kansantaloudelle todellisuudessa aiheuttamia kustannuksia. Nykyiset tariffit suosivat raaka-aineiden kuljetuksią valmiiden tuotteiden kuljetuksiin verrattuna, ja ne suosivat erityisesti kaukokuljetuksia. Näin meillä kannattaa kuljettaa esim. pyöreätä puuta aina Kemistä Helsinkiin saakka. - Kun esim. valmiin selluloosan kuljetus sitoo vain kymmenennen osan siitä vaunumäärästä, mikä sitä vastaavan raaka-ainemäärän kuljetukseen tarvitaan, havaitaan, että raakaaineiden kaukokuljetukset aiheuttavat kansantaloudelle suuria ylimääräisiä kustannuksia. Harkittaessa tuotantolaitosten sijoitusta valtakunnallisessa mielessä olisi tämäkin seikka otettava huomioon.

Voimatariffit. Edellä sanottu koskee myös voimatariffeja. Sijoituspaikkaa valittaessa ei voida ottaa perusteeksi käypää hintaa, vaan sähkövoiman kehityskustannuksiin on lisättävä voiman sirrosta voimalaitoksilta kullekin paikkakunnalle aiheutuvat todelliset siirtokustannukset. Vasta silloin voidaan verrata eri sijoituspaikkojen suhteellista edullisuutta toisiinsa.

Sosiaaliset tekijät. Mitä asuntokysymykseen tulee, on huomattava, että valtiovalta uhraa nykyään suuria summia teollisuuden työntekijöiden asuntojen rakentamiseen. Jos teollisuuslaitos tulisi perustettavaksi sellaiselle maaseudun paikkakunnalle, missä ei valtion tukea saada, asuntojen rakentaminen aiheuttaisi niin suuren ylimääräisen kustannuserän yrittäjälle, että hän joutuisi ilmeisesti hylkäämään tällaisen paikan, vaikka sillä olisi muuten hyvät edellytykset voittaa sijaintipaikasta kilpailtaessa. Tässäkin muodostuisi ratkaisu yrittäjän kannalta toiseksi, kuin mitä se voi olla yhteiskunnan kokonaisedun kannalta. 
Kevyt ja pienteollisuus. Kevyessä ja pienteollisuudessa mahdollisuudet sijaintipaikan valintaan nähden ovat paljon suuremmat kuin raskaassa teollisuudessa. Sekä kevyen että pienteollisuuden harjoittaminen on ratkaisevassa määrin riippuvainen yrittäjän henkilökohtaisista ominaisuuksista, ennen muuta ammattitaidosta. Noiden teollisuuksien tarvitsemat raaka-aineet voidaan kuljettaa pitkienkin matkojen takaa, ja niiden tuotteiden arvo painoyksikköä kohden on yleensä niin korkea, että kuljetuskustannukset eivät esitä ratkaisevaa osaa.

Teollisuuden la ajenemismahdollisuuksista. Teollisuuden sijaintiongelmaa joudutaan harkitsemaan lähinnä uutta teollisuutta perustettaessa. Vanhojen teollisuuslaitosten siirtohan voi tulla vain perin harvoissa tapauksissa kysymykseen. Näin ollen mahdollisuudet sijoittaa teollisuutemme nykyistä tasaisemmin valtakunnan eri osiin riippuvat ratkaisevasti tämän elinkeinon laajenemismahdollisuuksista.

Suurteollisuuden laajenemismahdollisuuksia on tarkastellut ns. teollistamiskomitea. Se on mm. todennut, että kaivosteollisuuden käyttämät, nykyisin tiedossa olevat malmivarat ehtyvät muutamassa vuosikymmenessä, ellei uusia käyttökelpoisia mineraaleja löydetä. Malmien etsintää olisi tehostettava, sillä yleisenä toteamuksena on havaittu, että mitä tehokkaammin etsintää suoritetaan, sitä enemmän uusia mineraaleja löydetään. Malmien etsintää suoritetaan ns. lohkarelöytöjen perusteella ja toisaalta erilaisia herkkiä sähkökojeita käyttäen joko maasta tai ilmasta käsin. Ns. aeroprospektaus, lentokoneesta käsin suoritettu etsintä, antaa tietoja hyvin nopeasti, ja sitä tehostamalla voidaan asiantuntijoiden käsityksen mukaan lähimpien kolmenkymmenen vuoden aikana kartoittaa ainakin pääosa maaperässämme esiintyvistä mineraaleista. Valtakunnan talouselämän tulevaa suunnitelmallista kehitystä ajatellen olisi sen vuoksi erittäin tärkeätä kehittää malmien etsintään liittyvää tutkimustyötä. Näin vahvistettaisiin raskaan teollisuutemme kotimaista raaka-ainepohjaa ja luotaisiin se nykyistä monipuolisemmaksi ja myös kilpailukykyisemmäksi. 
Kotoisiin raaka-aineisiin perustuvasta muusta suurteollisuudesta on puunjalostusteollisuudella vielä huomattavia laajenemismahdollisuuksia. Teollistamiskomitea katsookin, että teollisen jalostustoiminnan piiriin voitaisiin Oulujoesta pohjoiseen sijaitsevalta alueelta saada puuraaka-ainetta n. $800000 \mathrm{~m}^{3}$, jonka jalostaminen edellyttäisi neljän uuden selluloosatehtaan perustamista pohjois-Suomeen. Näiden uusien tehtaiden sijoituspaikkojen valinta vaikuttaa huomattavalla tavalla koko pohjois-Suomen talouselämän tulevaan kehitykseen.

Suurteollisuutta ja nimenomaan vientiteollisuutta ajatellen voitaisiin sanoa, että pääkysymys sijoitusongelmaa ratkaistaessa meillä on siinä, rakennetaanko tehdas raaka-ainelähteelle vaiko meren rannikolle, jota viimeksi mainittua voidaan pitää myös markkinapaikkana (oikeastaan lähimpänä markkinoita sijaitsevana paikkana).

Alkutuotannon sijoittaminen sumniftelun perusta. Alkutuotannon alueellinen sijoittuminen, maa- ja metsätalouden toisaalta ja teollisen tuotannon toisaalta, on siis keskeisenä perustana kaikelle valtakunnalliselle suunnittelutyölle. Vasta sitten, kun on nähtävissä suuret linjat tuotantotoiminnan kehittämiseksi pitkällä tähtäimellä, voidaan ryhtyä ns. asutuksen suunnitteluun. Eihän voida esim. lähteä sijoittamaan liikennereittejä johonkin suunnitelmaan, määrittelemään asuntoalueiden laajuutta, tarvittavia ns. yleisiä alueita tms., ellei tiedetä, miten tuotantotoiminta todennäköisesti po. paikkakunnalla kehittyy. Sen vuoksi on aiheellista korostaa sen seikan tärkeyttä, että kaiken suunnittelun täytyy lähteä tuotannon suunnittelusta, ja suunnittelun täytyy pyrkiä edistämään maamme tuotantovoimien hyväksikäyttöä. Tällöin on pyrittävä valtakunnalliseen kokonaiskatsomukseen, mikä erityisesti vaatii sitä, ettei tarkastella asioita ahtaasti esim. maa- ja metsätalouden tai teollisuuden kannalta, vaan otetaan huomioon, että valtakunnan talouselämä muodostaa yhden kokonaisuuden. 


\section{Liikennekysymykset.}

Kun edellä esitetyn perusteella tarkastellaan valtakunnallisia liikennekysymyksiä, todetaan, että rautatie- ja maantieverkon, sisävesiliikenteen ja satamien kehitystä on johdettava niin, että liikenne palvelee maan talouselämää mahdollisimman tehokkaasti. Jos haluttaisiin määritellä pääsuunnat rautatie- ja maantieverkolfemme, olisi eräs sellainen suunta koillisesta lounaaseen. Tämä pääsuunta merkitsee lyhintä kuljetusmatkaa rannikoille, joihin tuotteet sisämaasta hakeutuvat. Lähtemättä näitäkään ongelmia yksityskohtaisemmin pohtimaan joutuu kysymään, onko esim. maamme runkotiesysteemi, jonka keskipiste on Helsingissä, mistä runkotiet hajautuvat viuhkamaisesti valtakunnan eri osiin, kokonaisuutta ajatellen paras mahdollinen runkotiekysymyksen ratkaisu.

Sisämaan yhteydet satamiin ovat monessa tapauksessa vielä epätyydyttävät. Toisaalta satamienkaan kohdalla ei ole valtakunnallista rakennus- ja kehitysohjelmaa, vaan kun satamat ovat yleensä kunnallisia laitoksia, yrittävät kaikki rannikkokaupungit laajentaa satamiaan siitä riippumatta, onko niillä luontaisia kehitysedellytyksiä vai ei.

Liikennekysymysten kohdalla, jos missään, tarvittaisiin valtakunnallista tutkimusta ja selvittelytyötä. Eri vaihtoehtoja olisi voitava punnita asiallisilla perusteilla. Esim. olisi selvitettävä, missä maantie voi korvata rautatien, miten sisävesiliikenne niveltyy tämän päivän muuttuvaan liikennekuvaan ja mitä uusia yhteyksiä olisi kiireellisesti rakennettava.

\section{Asutuksen suunnittelu.}

Mitä lopuksi varsinaisen asutuksen suunnitteluun tulee, olisı siinäkin entistä enemmän tarkasteltava ongelmia valtakunnallisesti ja samalla alueellisesti. Väestökeskus ja sitä ympäröivä maaseutu muodostavat kokonaisuuden, jonka osien pitäisi mahdollisimman sopusointuisesti liittyä toisiinsa. Viime aikoina on usein tuotu 
esiin ajatus: keskuksia on väljennettävä, maaseutua tiivistettävä. Samoin on pohdittu kysymystä siitä, millaista keskuksen kokoa on kussakin tapauksessa pidettävä taloudellisesti ja sosiaalisesti edullisimpana ja miten maaseutuasutus nykyajan muuttuneissa olosuhteissa olisi järjestettävä. On ilmeistä, että asutuksen suunnittelussa on pyrittävä edistämään ns. luonnollisten talousalueiden puitteissa muovautuvaa alueellista asutusta. Erityisesti joudutaan huomiota kiinnittämään niihin talousalueisiin, joiden tuotantotoiminnan pohja on toistaiseksi liian kapea, mutta joiden alueilla on vielä käyttämättömiä voimavaroja. Olosuhteisiin sopeutuvalla asutuksen suunnittelulla voidaan juurị mainituille alueille luoda uutta tuotantoa ja siten rikastuttaa koko kansantalouttamme.

Edelleen on ratkaistava kysymys siitä, miten valtakunnan hallinto on järjestettävä sekä mihin kulttuurilaitokset ja muut yleiset laitokset olisi sijoitettava, jotta koko valtakunnan asujaimisto saisi niistä suurimman mahdollisen hyödyn. Nämä kaikki ovat kysymyksiä, jotka vaativat perusteellisia tutkimuksia. Ne ovat ongelmia, joiden selvittäminen muodostaa aivan oman tieteenhaaransa, mitä voisimme nimittää yhteiskunnansuunnitteluksi.

\section{Suunnitteluelin.}

On ilmeistä, että erilaiset pitkän tähtäimen suunnittelutehtävät lähivuosina nykyisestään lisääntyvät. Näiden tehtävien suorittamisessa tarvitaan koulutettua työvoimaa. Kysymyksessä on kuitenkin niin monipuolinen työ, ettei kukaan ammattimies yksin voi koko ongelmaryhmää hallita. Sen vuoksi on saatava aikaan eri alojen edustajien yhteistyö.

Koettelemalla ja korjailemalla voidaan hapuilla eteenpäin pienissä asioissa. Suurissa, koko valtakuntaa koskevissa kysymyksissä tällainen menettely ei kestä arvostelua. Niitä ratkaistaessa tarvitaan suunnittelua, sillä vain tutkimusten, selvittelyjen ja suunnittelun avulla voidaan välttää monet erehdykset. Nyt herää kysymys: miten valtakunnallinen suunnittelutyö sitten olisi organisoitava? Meillä on jo olemassa eri alojen tutkimuslaitoksia, jotka 
suorittavat arvokasta tutkimustyötä. Näitä on käytettävä hyväksi mahdollisimman pitkälle ja varottava yliorganisointia.- Kuitenkin tuntuu siltä, että valtioneuvoston yhteydessä toimiva, asiantuntijoista kokoonpantu valtakunnallinen suunnitteluelin voisi parhaiten pitää yhteyttä eri tutkimuslaitoksiin, koota tarvittavaa jo valmista materiaalia sekä suunnitella, mitä tutkimuksia tarvitaan ja miten kussakin tapauksessa tarvittavia tietoja nopeimmin ja halvimmin kustannuksin saataisiin hankituksi. Tämän elimen tehtävänä olisi myös pitää yhteyttä paikallisiin suunnitteluelimiin. Näin voitaisiin paikallisessa suunnittelutyössä ottaa huomioon valtakunnalliset tavoitteet, ja toisaalta kunkin alueen erikoisolosuhteet olisivat riittävästi selvillä koko valtakuntaa koskevia suunnitelmia laadittaessa. 